\title{
Recurrent High Grade B-Cell Lymphoma with MYC, BCL2, and BCL6 Rearrangements
}

National Cancer Institute

\section{Source}

National Cancer Institute. Recurrent High Grade B-Cell Lymphoma with MYC, BCL2, and BCL6 Rearrangements. NCI Thesaurus. Code C162451.

The reemergence of high grade B-cell lymphoma with MYC, BCL2, and BCL6 rearrangements after a period of remission. 